\title{
HOME DELIVERY: CONCEPT AND CHARACTERISTICS
}

\author{
Snežana Tadić ${ }^{1}$, Miloš Veljović ${ }^{2}$ \\ 1,2 University of Belgrade, Faculty of Transport and Traffic Engineering, Vojvode Stepe 305, 11000 \\ Belgrade, Serbia
}

Received 18 June 2020; accepted 25 August 2020

\begin{abstract}
Due to the development of e-commerce and specific customer habits and requirements, in recent decades an increasing number of companies offer home delivery service, which is the flow of goods from the business to the consumer (B2C) at the end of the supply chain ("last mile"). The main characteristic and difference of home delivery in relation to other ways of supplying customers/households (traditional customer purchase, "click \& collect" purchase, door-to-door sales) is the engagement of companies in picking/physical preparation and delivery of ordered goods to customers. Delivery characteristics depend on a number of factors and circumstances, preferences, goals and interests of stakeholders (customers, companies, governments), but there is also a strong interdependence, with the type of goods having a dominant influence on other delivery characteristics. Planning, organization and implementation of the process of ordering, picking, delivery and return of goods are a serious challenge for companies' logistics and information systems, generate high costs, increase freight transport and have a significant impact on the environment. Therefore, delivery characteristics are an important area of research and optimization of systems that implement this service. This paper analyzes the concept, basic characteristics and criteria for structuring home deliveries. In this way, the systematization of basic scientific knowledge about home delivery was performed and the basis for future research of various aspects of this field was created.
\end{abstract}

Keywords: home delivery, last mile, B2C, concept, characteristics, criteria, structuring.

\section{Introduction}

There are different ways to supply households. Prior to the emergence of supermarkets and large retail chains, door-to-door sales, regular scheduled home delivery of milk and other groceries from local stores were common practice (Gould, 1998; Browne et al., 2001; Hays et al., 2005). Mass use of cars, expansion of the network of supermarkets and retail chains, significantly change the supply of households. Supermarkets offer lower margins for goods that are traditionally delivered to customer home address. In addition, there is a development of a wide range of different types of goods. This encourages customers to realize the supply independently and almost completely suppresses home delivery. The offer of goods that generates specific logistical demands, primarily in terms of dimensions and values (furniture, white goods, etc.), and the development of new forms of ordering goods (mail, telephone) enable the survival of home delivery, but to a much lesser extent. In parallel with the magnification and differentiation of supply and demand and

\footnotetext{
${ }^{1}$ Corresponding author: s.tadic@sf.bg.ac.rs
} 
the growth of consumerist habits, there is an accelerated technological development. The emergence of the Internet, as one of the main achievements of this development, has enabled the development of the concept of e-commerce, which in recent decades has transformed the relationship between companies and customers. Encouraged by the development of e-commerce, companies are expanding their business from a physical to an online channel ("click \& mortar") and re-establishing home delivery services, but in significantly different circumstances and with different, often unpredictable effects on the environment and stakeholders.

Home delivery or last mile delivery is the supply chain phase that includes the activities by which goods are physically moved to the customer (Agatz et al., 2008b). As such, it represents the flow of goods between the company and the customer (B2C). Such flows differ in relation to the flows realized in the traditional distribution system between companies (business to business - B2B): producers, wholesalers and retailers $(\mathrm{Du}$ et al., 2005; Van Duin et al., 2016). Namely, B2B flows are characterized by a large volume, more efficient use of means of transport and other resources and a higher degree of determinism in terms of place, time, amount of demands, etc. (Visser et al., 2014). On the other hand, due to the number and spatial dispersion of customers (Tadić \& Veljović, $2020 a$ ) and the characteristics of the demands, B2C flows have significantly lower efficiency (Van Duin et al., 2016). Divergent distribution structure, a large number of small orders, heterogeneous and changing customer demands are serious challenges for delivery service providers (Tadić et al., 2017; Moroz \& Polkowski, 2016; Du et al., 2005).

There are a number of potential benefits of home delivery for customers, companies and society (Cairns, 1996): making company profits, keeping community shops/spirit going, encouraging the purchase of local produce, reducing car traffic and providing social services (services for people who are unable to move: old, the sick, the disabled, persons under house arrest, persons who do not own means of transport, persons in remote and inaccessible areas etc.). The importance of home delivery is especially pronounced in the conditions of impossible movement, which was confirmed during the COVID-19 pandemic (Hobbs, 2020). In the conditions of home isolation, home deliveries enabled the supply of households and the survival of shops, restaurants and other companies that provide this service. In addition to when necessary, delivery is applied in order to increase customer satisfaction (Morganosky \& Cude, 2000), to save time and avoid the traditional way of shopping due to crowds, specific logistical demands etc. (Browne et al., 2001). Also, research shows that the application of some variants of home delivery or their combination with the traditional way of shopping contributes to a significant reduction in costs compared to the purchase that is realized exclusively in the traditional way (up to $43 \%$, Punakivi \& Saranen, 2001). On the other hand, there are numerous shortcomings, problems and challenges in the application of home delivery. Last mile delivery is the most expensive part of the supply chain (Vanelslander et al., 2013; Kuhn \& Sternbeck, 2013; Fernie et al., 2010; Gevaers et al., 2009). Fragmentation of shipments, which is inherent in home delivery, can lead to an increase in freight transport (Cárdenas et al., 2017; Taniguchi \& Kakimoto, 2004), and thus to congestion, harmful emissions, noise, security threats in residential areas, etc. The consequences 
of these effects are particularly pronounced in central urban areas, given the high concentration of different functions (housing, trade, tourism, etc.) (Tadić, 2019). Also, the specificity and fluctuations of demand and the challenges of the logistics system for the realization of deliveries can lead to serious problems, and even bankruptcy and termination of companies (Fernie et al., 2010; Campbell \& Savelsbergh, 2005; Kämäräinen \& Punakivi, 2002). Therefore, delivery characteristics are an important area of research and optimization of systems that implement this service.

This paper analyzes the concept and basic characteristics of home delivery. The main contribution and goal of the paper is the systematization of basic scientific knowledge about home delivery. Also, based on the characteristics of deliveries, the criteria for their structuring are defined, which created the basis for future research on various aspects of this area.

The paper is organized as follows. After the introduction, a review of the literature dealing with the concept, significance, effects and characteristics of home delivery is given. Chapter 3 deals with the concept and definitions of home delivery and last mile delivery. Chapter 4 analyzes the characteristics and criteria for structuring home deliveries. After that, conclusions and directions of future research are given.

\section{Literature Review}

In recent decades, a growing number of papers have addressed the concept, significance, effects, characteristics, structuring and classifications of home delivery. Numerous papers provide definitions of home delivery (Agatz et al., 2008b; Browne et al., 2001) and last mile delivery (Lim et al., 2018; Wohlrab et al., 2012; Lindner, 2011; Gevaers et al., 2009; Allen et al., 2007). The importance and effects of home delivery and e-commerce as their primary generator have also been the subject of numerous studies, primarily in the context of freight transport (Visser et al., 2014; Gevaers et al., 2014; Esser \& Kurte, 2005; Taniguchi \& Kakimoto, 2004; Hesse, 2002), environmental impacts (Brown \& Guiffrida, 2014; Edwards et al., 2009; 2010a; 2010b) and social role (Cairns, 1996).

The subject of research are also the characteristics of delivery. Customer satisfaction with the service is most directly influenced by the end point of delivery and the method of receiving the goods. Although the home address is the most common end point of delivery, in a very small number of papers, households are analyzed in more detail as the place of receipt of goods (Tadić \& Veljović, 2020a). On the other hand, the attention of a large number of researchers has been drawn to collection and delivery points (CDPs) (Van Duin et al., 2016; Morganti et al., 2014a; 2014b; Weltevreden \& RotemMindali, 2009; Weltevreden, 2008; McLeod et al., 2006). Two types of CDPs that exist in practice are discussed in the papers: attended (Song et al., 2009) and unattended (Yuen et al., 2018; Iwan et al., 2016). Equal attention of researchers as the end point of delivery has the method of receiving goods (Punakivi, 2003; McKinnon \& Tallam, 2003). Deliveries can be made in the presence (attended delivery) (Agatz et al., 2008a) or without the presence of the customer (unattended delivery) (Fernie \& McKinnon, 2009; Xu et al., 2008). Several papers analyze different solutions for unattended delivery: the use of reception and delivery boxes (Kämäräinen $e t$ al., 2001; Punakivi et al., 2001) and delivery to the trunk of the customer's vehicle 
(Reyes et al., 2017; Ozbaygin et al., 2017). Speed (Dablanc et al., 2017; Hausmann et al., 2014) and delivery time (Klein et al., 2019; Agatz et al., 2011; Yaman et al., 2012; Campbell \& Savelsbergh, 2006) have similar significance, but significantly less attention from researchers in relation to the previous characteristics. In many studies, delivery characteristics have been analyzed by different types of goods (Gevaers et al., 2009; Daduna \& Lenz, 2005; Browne et al., 2001), and grocery delivery has attracted the greatest attention from researchers (Durand \& Gonzalez-Feliu, 2012; Campbell \& Savelsbergh, 2005; Lin \& Mahmassani, 2002; Yrjölä, 2001; Punakivi \& Saranen, 2001). The place and technology of picking are also very often analyzed in the literature (Hays et al., 2005; Murphy, 2003; De Koster, 2002; Kämäräinen \& Punakivi, 2002). Researchers are particularly interested in drop-shipping concept of delivery, which involves picking at the manufacturer's location and direct delivery to the customer (Gan et al., 2010; Ayanso et al., 2006). Numerous papers are dedicated to different delivery executors: courier, express and parcel services (CEPs) (Park et al., 2016; Ducret, 2014; Menge \& Hebes, 2011) and crowd-workers (Arslan et al., 2018; Carbone et al., 2017; Devari et al., 2017; Wang et al., 2016; Mehmann et al., 2015). Ordering and paying systems have been considered without going into details, except for electronic ones, which have become increasingly important in recent decades (Morganti et al., 2014b). Return flows in home delivery have been analyzed in several papers (Tadić \& Veljović, 2020b; Bernon et al., 2016; Morganti et al., 2014b; Browne et al., 2001). A large number of papers analyze e-commerce and home delivery in the context of urban areas (Dablanc et al., 2017; Visser et al., 2014; Gevaers et al., 2014; Ehmke \& Campbell, 2014; Ehmke
\& Mattfeld, 2012; Durand \& GonzalezFeliu, 2012; Gevaers et al., 2011), and a significantly smaller number of papers also address delivery in rural areas (Morganti et al., 2014a; Boyer et al., 2009). The smallest number of studies deals with frequency and area of delivery in terms of coverage (local, regional, national, etc.) (De Koster, 2003).

\section{The Concept of Home Delivery}

Numerous terms are related to the delivery of goods to customers, i.e. to households. They have a similar meaning, but emphasize certain aspects: last mile(s) delivery, final delivery, home delivery, residential delivery, door-to-door delivery, doorstep delivery, consumer direct service delivery, B2C e-commerce delivery, extended supply chain etc. The terms last mile delivery and final delivery indicate a place in the supply chain (SC). SC that involves the delivery of goods to the customer is sometimes called a last mile SC or extended SC (Boyer et al., 2003). Home delivery, residential delivery, door-to-door delivery and doorstep delivery specify the end point of delivery. The term consumer direct service delivery emphasizes direct interaction with customers, while B2C e-commerce delivery also refers to e-commerce as the basic generator of home delivery. Some of these terms are more common in the literature (e.g. last mile delivery, final delivery, B2C e-commerce delivery), while some are more commonly used in the market (e.g. doorstep delivery).

Along with the term last mile delivery, in the literature, but also on the market, the term home delivery dominates. These terms, their interpretations and definitions differ in terms of comprehensiveness and are used in different contexts. The different level of coverage of the term last mile refers to 
the parties involved (B2C, consumer to consumer - C2C), the supply chain segment, the starting and ending point of delivery, flow executors etc. According to Allen et al. (2007), last mile delivery is the logistics element of the fulfilment process, expressed through various ordering systems, including B2C and C2C transactions. On the other hand, Gevaers et al. (2009), Wohlrab et al. (2012) and Lim et al. (2018) limit last mile delivery to B2C trade. Early definitions refer to the last mile as "extension of supply chains directly to the end consumer" (Punakivi et al., 2001; Boyer et al., 2005; Kull et al., 2007; Lim et al., 2018). According to Lindner (2011), last-mile delivery involves "a series of activities and processes that are necessary for the delivery process from the last transit point to the final drop point of the delivery chain". The final drop point can be the store, company, factory, or residence of the customer (Dablanc et al., 2013). However, although the term "last mile" itself indicates a narrow geographical area, marking the last transit point as the starting point of last mile delivery can significantly reduce the meaning of this term and change the context in which it is most commonly used. Thus, the last transit point can be the customer's neighbor's household, the customer's workplace or the CDP. In this case, the term "last mile" does not cover the complexity of the organization of delivery on the part of the supplier, but means a very short segment, which is usually realized by the customer. Therefore, Lim et al. (2018) the term last mile denotes the segment from the order penetration point to the final consignee's preferred destination point. The order penetration point indicates the point of the stock, at which the customer order activates the order fulfilment process (Oldhager, 2003; Fernie \& McKinnon, 2009). Also, although most often, the term last mile logistics is not only related to delivery, but also to other ways of supplying the household, including the traditional way of procurement, door-to-door sales and "click \& collect" procurement (Slabinac, 2015; Agatz et al., 2008b; Daduna \& Lenz; 2005). In this context, last mile logistics has a broader meaning than the term home delivery, which clearly indicates that the goods are being sent to the customer's residence or place nearby (Punakivi, 2003; Fernie \& McKinnon, 2009). Despite the nuances in the interpretation, the existing definitions of the last mile connect the understanding of this term as the last part of the delivery process (Lim et al., 2018).

Home delivery in a narrower sense implies direct delivery to the customer's home address (Morganti et al., 2014b; Gevaers et al., 2009), and in a broader sense delivery that can be realized directly or through other points near the home address (neighbor's household, workplace, CDP, drop off company etc.) (Visser et al., 2014; Punakivi, 2003). Browne et al. (2001) emphasize the difference from traditional shopping and define home delivery as the delivery of goods to a home address or other location of the customer's choice, made by companies rather than by customer. The involvement of the retailer/producer in the organization of household supply flows is the basic feature and the difference of home delivery in relation to other forms of supply in the last mile. Unlike the traditional method of procurement (customer picking and delivers the goods to the household), the "click \& collect" variant (retailer/ manufacturer prepares the customer's order and the customer realizes the delivery to the household), and door-to-door sales (where the retailer delivers goods to the household, and the customer then selects/ picks them), when delivered to the home 
address, the retailer/manufacturer is involved in both the goods picking and the organization of its delivery to the household. The retailer/manufacturer can deliver the goods independently, by hiring a logistics provider or a crowd worker, to the customer's home address or other locations. Although some definitions exclude the participation of the customer in the realization of deliveries (Browne et al., 2001), he most often realizes the delivery of goods from CDP and other locations to the home address. Thus, home delivery can be defined as direct or indirect delivery of goods to the customer home address, which is partially or fully realized by the retailer, manufacturer or third party (logistics provider, crowd worker).

\section{Characteristics of Home Deliveries}

The characteristics of home delivery affect the level of service, the level of demand and customer satisfaction, efficiency, costs and profitability of the delivery organizer, as well as the environment in which these processes take place. Some of the characteristics and parameters of delivery are almost completely controlled by the organizer (e.g. start point, return flows) (Vanelslander et al., 2013), and others are primarily related to customer decisions (e.g. end point of delivery) (Lim et al., 2018), but most of them depend on a number of circumstances and factors related to different stakeholders.

One of the key characteristics of home delivery, which is very little discussed in the literature, is the connection between the process of ordering, payment, picking and taking over products, i.e. between flows of information, money and goods (Tadić \& Veljović; 2020a). These processes/flows can be spatially and temporally separated or connected. Gardrat et al. (2016) indicate that the spatial and temporal separation of the purchase and taking goods are the basic characteristics of home delivery. At the same time, these characteristics represent the main differences between home delivery in relation to traditional buying and door-to-door sales. Delivery is realized after in-person or remote ordering, and the goods are taken at the home address or other locations agreed between the customer and the delivery organizer. Spatial and temporal separation is further expressed with the development of new concepts related to different places and methods of ordering, payment, order picking and taking goods and different delivery executors, described in the following points. Spatial and temporal separation of the processes, which is often inherent in home delivery, makes numerous benefits, but also risks for both the customer and the retailer and other stakeholders. For example, the spatial and temporal separation of ordering and order picking/physical preparation may result in the delivery of goods that by type, quality, quantity and other parameters do not match the ordered, and these parameters can be much easier to control in the case of traditional and door-todoor selling. Also, the separation of ordering, payment and taking goods allows for various abuses by the delivery organizer/executor, customer or other persons. The risks are especially pronounced when paying online and unattended delivering (using a reception box, delivery box, placing the goods in front of the customer's facility etc.). Namely, the supplier can claim that he delivered the goods, even though he did not do so, or that he did not receive the money, even though the online transaction was realized, just as the customer can claim that he did not receive the goods, even though the receipt was realized. Also, other persons can steal the goods that were delivered without the presence of the customer. 
However, although the development of new sales channels develops forms of purchase that by their nature imply the spatial and temporal separation of key processes (online ordering from the house - pick-up in the store, ordering in the store - home delivery, etc.), home delivery does not it must necessarily imply the separation of all processes. The term home shopping indicates that the customer places the order at home (or in other locations except the store), where he can also receive the ordered goods. One of the basic benefits of this delivery for the customer is the lack of need for mobility and absence of difference between the place of ordering and taking goods. The spatial separation of these processes can also be questioned in the case of regular scheduled deliveries. During one delivery, the customer and the delivery executor can agree on the realization of the next delivery, whereby ordering and taking over the goods are performed at the same place. Also, payment is usually spatially and temporally related to the processes of ordering or taking over goods.

By analyzing and systematizing the basic characteristics of home deliveries, the criteria for their structuring can be singled out (Fig. 1). There is an interdependence between the characteristics/criteria, and the type of goods has the most pronounced influence on other delivery characteristics (Table 1).

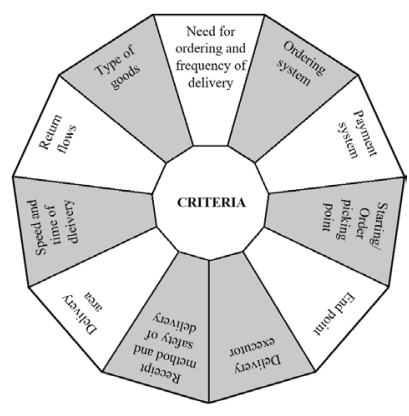

Fig. 1.

Criteria for Structuring Home Delivery

The characteristics of the goods and the way they are used affect the need for ordering and the frequency of delivery. Non-food, durable goods are ordered by the customer when the need arises and they are delivered independently of other deliveries that the retailer realizes for the same customer. The customer can also order non-durable, consumer goods when the need arises, but since the needs for these goods are constant and much more predictable, they are often delivered at a predetermined frequency, which completely or partially eliminates ordering activities. The characteristics of the goods also affect the ordering system. Standardized low value goods are suitable for remote ordering (online, telephone, mail, etc.), unlike shopping goods (clothing, footwear, etc.), large goods (furniture, white goods, etc.), high-value items (gold items, high-value jewelry and electronics etc.) and goods characterized by differences between product units (fruits, vegetables, flowers, etc.), which customers more often personally choose and order in the store, in order to have a complete insight into its characteristics. 


\section{Table 1}

Influence of the Type of Goods on Other Characteristics of Home Delivery

\begin{tabular}{|c|c|c|c|c|c|}
\hline \multirow[b]{2}{*}{ Type of Goods } & \multirow[b]{2}{*}{\begin{tabular}{|c|}
$\begin{array}{c}\text { Non-durable Goods } \\
\text { (food, cosmetics, } \\
\text { hygiene and cleaning } \\
\text { products, other } \\
\text { household consumables, } \\
\text { flowers, etc.) }\end{array}$ \\
\end{tabular}} & \multicolumn{2}{|c|}{ Small Durable Goods } & \multicolumn{2}{|c|}{ Large Durable Goods } \\
\hline & & $\begin{array}{l}\text { Low Value } \\
\text { Goods (books, } \\
\text { CDs, clothes, } \\
\text { shoes, etc.) }\end{array}$ & \begin{tabular}{|} 
High Value \\
Goods \\
(jewelry, \\
electronics, \\
etc.)
\end{tabular} & \begin{tabular}{|} 
High Value \\
Goods (e.g. \\
some building \\
materials)
\end{tabular} & $\begin{array}{l}\text { High Value } \\
\text { Goods } \\
\text { (furniture, } \\
\text { white goods, } \\
\text { etc.) }\end{array}$ \\
\hline $\begin{array}{l}\text { Need for } \\
\text { Ordering }\end{array}$ & $\begin{array}{l}\text { Ordering when the need for } \\
\text { goods arises (e.g. delivery } \\
\text { of prepared food) or regular } \\
\text { scheduled delivery of goods } \\
\text { (partially or completely } \\
\text { without ordering) that has } \\
\text { a constant dynamics of } \\
\text { consumption (e.g. grocery } \\
\text { delivery) }\end{array}$ & \multicolumn{2}{|c|}{$\begin{array}{l}\text { Ordering when the need for } \\
\text { goods arises }\end{array}$} & \multicolumn{2}{|c|}{$\begin{array}{l}\text { Ordering when the need for } \\
\text { goods arises }\end{array}$} \\
\hline $\begin{array}{l}\text { Frequency of } \\
\text { Delivery }\end{array}$ & $\begin{array}{c}\text { There is no regularity } \\
\text { of deliveries in time or } \\
\text { the customer requires a } \\
\text { high and predetermined } \\
\text { frequency }\end{array}$ & \multicolumn{2}{|c|}{$\begin{array}{l}\text { Low frequency, there is no } \\
\text { regularity of deliveries in time }\end{array}$} & \multicolumn{2}{|c|}{$\begin{array}{l}\text { Low frequency, there is no } \\
\text { regularity of deliveries in time }\end{array}$} \\
\hline $\begin{array}{l}\text { Ordering } \\
\text { System }\end{array}$ & $\begin{array}{c}\text { Usually online, but it is } \\
\text { also realized in-person in } \\
\text { store (e.g. fruit, vegetables, } \\
\text { flowers) or in the household } \\
\text { during regular scheduled } \\
\text { delivery (e.g. milk) }\end{array}$ & $\begin{array}{l}\text { Online, by } \\
\text { phone, mail or } \\
\text { in person in } \\
\text { store }\end{array}$ & $\begin{array}{l}\text { Usually in } \\
\text { person in store }\end{array}$ & $\begin{array}{l}\text { Online, by phone } \\
\text { or in person in } \\
\text { store }\end{array}$ & $\begin{array}{c}\text { Usually in } \\
\text { person in store }\end{array}$ \\
\hline Payment System & $\begin{array}{c}\text { Online/mobile payment, } \\
\text { using a credit card or cash } \\
\text { payment }\end{array}$ & \multicolumn{2}{|c|}{$\begin{array}{l}\text { Online/mobile payment, using a } \\
\text { credit card or cash payment }\end{array}$} & \multicolumn{2}{|c|}{$\begin{array}{c}\text { Usually using a credit card or cash } \\
\text { payment }\end{array}$} \\
\hline $\begin{array}{l}\text { Starting/Order } \\
\text { Picking Point }\end{array}$ & $\begin{array}{l}\text { Usually a store, but it can } \\
\text { also be a logistics center of } \\
\text { the retailer }\end{array}$ & \multicolumn{2}{|c|}{$\begin{array}{c}\text { Usually the logistics center of } \\
\text { the retailer or the location of the } \\
\text { manufacturer, but it can also be } \\
\text { a store }\end{array}$} & \multicolumn{2}{|c|}{$\begin{array}{l}\text { Store, retailer's logistics center or } \\
\text { manufacturer's location }\end{array}$} \\
\hline End Point & Customer's home address & \multicolumn{2}{|c|}{$\begin{array}{c}\text { Customer's home address, } \\
\text { neighbour's household, } \\
\text { customer's workplace, CDP }\end{array}$} & \multicolumn{2}{|c|}{ Customer's home address } \\
\hline Executor & $\begin{array}{l}\text { Usually retailer/ } \\
\text { manufacturer }\end{array}$ & \begin{tabular}{|c|}
$\begin{array}{c}\text { Usually CEPs or } \\
\text { crowd-worker }\end{array}$ \\
\end{tabular} & Usually retailer & \multicolumn{2}{|c|}{ Usually retailer/manufacturer } \\
\hline $\begin{array}{c}\text { Method of } \\
\text { Goods Receipt }\end{array}$ & $\begin{array}{c}\text { Attended or unattended } \\
\text { delivery (using reception or } \\
\text { delivery box) }\end{array}$ & \begin{tabular}{|c|} 
Attended or \\
unattended \\
delivery (using \\
mailbox, \\
delivery to CDP \\
etc.) \\
\end{tabular} & $\begin{array}{c}\text { Usually attended } \\
\text { delivery }\end{array}$ & $\begin{array}{l}\text { Attended or unatt } \\
\text { (access of the } \\
\text { household faci } \\
\text { approval of the }\end{array}$ & $\begin{array}{l}\text { tended delivery } \\
\text { vorker to the } \\
\text { lity with the } \\
\text { e customer) }\end{array}$ \\
\hline Delivery Speed & Require high speed & \multicolumn{2}{|c|}{ Not require high speed } & \multicolumn{2}{|c|}{ Not require high speed } \\
\hline Delivery Area & Usually a local, urban area & \multicolumn{2}{|c|}{$\begin{array}{c}\text { The goods do not limit delivery } \\
\text { area }\end{array}$} & \multicolumn{2}{|c|}{$\begin{array}{c}\text { The goods do not limit delivery } \\
\text { area }\end{array}$} \\
\hline Return Flows & $\begin{array}{c}\text { Low rate of return of goods, } \\
\text { higher rate of return of } \\
\text { packaging and logistics } \\
\text { units, complex realization } \\
\text { of flows }\end{array}$ & $\begin{array}{c}\text { Higher rate of } \\
\text { return of goods, } \\
\text { easier realization } \\
\text { of flows }\end{array}$ & $\begin{array}{l}\text { Low return rate } \\
\text { due to personal } \\
\text { order. and } \\
\text { increased risk of } \\
\text { theft or damage }\end{array}$ & $\begin{array}{c}\text { Low return rate, } \\
\text { except for unused } \\
\text { building material }\end{array}$ & $\begin{array}{l}\text { Low return } \\
\text { rate and } \\
\text { complex } \\
\text { realization of } \\
\text { flows }\end{array}$ \\
\hline
\end{tabular}


The type and value of goods also affect the payment system. Thus, customers are rarely paid online for high-value goods, when remote ordering goods, because there is a risk of fraud or inability to return the money in case of damage to the goods and (or) customer dissatisfaction. The type of goods also affects the place of picking, i.e. the starting point of delivery. Non-durable, consumer goods are sold in supermarkets, where they are usually picked before delivery. Deliveries of durable goods can also be made from stores (especially in the case of personal ordering), but are more often made from the retailer's logistics center or directly from the manufacturer (Browne et al., 2001; Agatz et al., 2008b; Fernie \& McKinnon, 2009). The end point of delivery and the method of receiving the goods also largely depend on the type, characteristics and value of the goods. Goods of large dimensions and (or) value are most often delivered to the home address in the presence of the customer (Weltevreden, 2008; Campbell \& Savelsbergh, 2006). Perishable goods also require such delivery or application of adequate reception or delivery boxes that are attached to the outer wall of the customer's facility. Low value and small goods, which do not generate specific logistical requirements, are suitable for delivery to other points (CDP, neighbor's household, customer's workplace) or unattended delivery, using mailboxes, putting goods in front of the customer's facility etc. The choice of delivery executor also depends on the type, value of the goods and the logistical demands it generates. For the delivery of durable small goods, retailers usually hire CEPs (Browne et al., 2001), and the delivery of non-durable and large durable goods is usually realized independently. For delivery of low value goods, the retailer can hire a crowd-worker, i.e. individuals who realize the delivery with their own resources, and their engagement for the delivery of high value goods brings the risk of theft (Devari et al., 2017). The specific requirements generated by some types of goods also affect the speed and area of delivery (Browne et al., 2001; Gevaers et al., 2009; Joerss et al., 2016). Thus, perishable (e.g. food) and time-sensitive goods (e.g. flowers, daily newspapers) require fast delivery, which is most often realized only in the local, urban area (Fernie \& McKinnon, 2009). Finally, the type of goods affects the return rate and the complexity of the realization of return flows. Due to complex logistics requirements and high delivery costs in relation to product margins, food and other non-durable goods are very rarely returned to the supplier, but the delivery of these goods often generates return flows of packaging and logistics units (Tadić \& Veljović, 2020b). Durable items of high value and (or) large dimensions are also rarely returned to the supplier due to specific logistical requirements (except for unused low-value building materials), while return flows of durable items of small dimensions are more frequent and much simpler.

\section{Conclusion}

In recent decades, due to the development of the Internet and e-commerce, an increasing number of companies offer a home delivery service. Unlike traditional and "click \& collect" purchases, which are realized by the customer, and door-to-door sales, home delivery involves engaging companies in picking/physical preparation and delivery of ordered goods to the customer's home address or location nearby. Delivery characteristics depend on a number of circumstances and stakeholder factors. The analysis of the characteristics of home delivery is important both in order to achieve benefits for customers and companies, and in 
the context of coordination and optimization of logistics flows in the area and their impact on the community and the environment.

In this paper, the concept and basic characteristics of home delivery are analyzed. The paper systematically collects the basic knowledge about the characteristics of home delivery, which achieves the basic goal and contribution of the paper. Also, based on the analysis and systematization of the characteristics of home delivery, the criteria for their structuring have been defined, which has created the basis for future research in this area.

Below are some of the directions of future research. The structuring and classification of home delivery according to the criteria defined in the paper and the analysis of the advantages, disadvantages and applicability of different models of home delivery are the next steps in the systematic research of the area. The capacity, efficiency and ability of the logistics system to respond to complex and changing requirements in the short (speed, reliability of delivery, etc.) and long term (increase in online shopping, seasonal demand, holidays, etc.) should also be the subject of future research.

Humanitarian home delivery, which is realized by charitable, social, rescue, local government services, may also be the subject of future research. The research of deliveries of humanitarian and commercial character, which are realized due to the disabled mobility of customers, is especially important having in mind the current, but also possible epidemics in the future. On the other hand, the attention of scientists should be focused on home delivery in the context of sure economic consequences of the COVID-19 pandemic (Gevaers, 2020).
In this sense, the key questions related to the role of home delivery in the future are: whether and to what extent the delivery service will be applied in the future, what will be the price of delivery and whether they will be a luxury and additional customer satisfaction or necessary way of household supply?

In addition to the economic, environmental and social aspects play a very important role in considering home delivery. Analyzes of the impact of different delivery models on the volume of passenger and freight transport, congestion, traffic safety in residential areas, harmful gas emissions, noise etc. are a wide field for future research.

In addition to the retailer, i.e. the delivery service provider, in future research of home delivery, a greater focus on the customer should be expected. In addition, a special challenge is to compare home deliveries with other forms of household supply (traditional purchase in the realization of the customer, "click \& collect", door-to-door sales).

\section{References}

Agatz, N.; Campbell, A.; Fleischmann, M.; Savelsbergh, M. 2008a. Challenges and Opportunities in Attended Home Delivery. In: Golden, B.; Raghavan, S.; Wasil, E. (Eds.), The Vehicle Routing Problem: Latest Advances and New Challenges. Operations Research/Computer Science Interfaces, vol. 43. Springer, Boston, 379-396.

Agatz, N.; Fleischmann, M.; Van Nunen, J. A. E. E. 2008b. E-fulfillment and multi-channel distribution - A review, European Journal of Operational Research, 187(2): 339-356.

Agatz, N.; Campbell, A.; Fleischmann, M.; Savelsbergh, M. 2011. Time Slot Management in Attended Home Delivery, Transportation Science 45(3): 435-449. 
Allen, J.; Thorne, G.; Browne, M. 2007. Good practice guide of urban freight transport, BESTUFS, Available from internet: http://www.bestufs.net/download/ BESTUFS_II/good_practice/English_BESTUFS Guide.pdf.

Arslan, A.M.; Agatz, N.; Kroon, L.; Zuidwijk, R. 2018. Crowdsourced Delivery - A Dynamic Pickup and Delivery Problem with Ad Hoc Drivers, Transportation Science 53(1): 1-14.

Ayanso, A; Diaby, M.; Nair, S. K. 2006. Inventory rationing via drop-shipping in Internet retailing: A sensitivity analysis, European Journal of Operational Research 171(1): 135-152.

Bernon, M.; Cullen, J.; Gorst, J. 2016. Online retail returns management, International Journal of Physical Distribution \& Logistics Management 46(6/7): 584-605.

Boyer, K. K.; Prud'homme, A. M; Chung, W. 2009. The Last Mile Challenge: Evaluating the Effects of Customer Density and Delivery Window Patterns, Journal of Business Logistics 30(1): 185-201.

Boyer, K.K.; Frohlich, M.T.; Hult, T.G. 2005. Extending the Supply Chain: How Cutting Edge Companies Bridge the Critical Last Mile into Customers' Homes. American Management Association, USA. 252 p.

Boyer, K.K.; Hult, G.T.; Frohlich, M. 2003. An exploratory analysis of extended grocery supply chain operations and home delivery, Integrated Manufacturing Systems 14(8): 652-663.

Brown, J. R.; Guiffrida, A. L. 2014. Carbon emissions comparison of last mile delivery versus customer pickup, International Journal of Logistics Research and Applications 17(6): 503-521.

Browne, M.; Allen, J.; Anderson, S; Jackson, M. 2001. Overview of home deliveries in the UK. University of Westminster and Freight Transport Association (FTA), a study for the DTI.
Cairns, S. 1996. Delivering alternatives, Transport Policy 3(4): 155-176.

Campbell, A. M.; Savelsbergh, M. W. P. 2005. Decision Support for Consumer Direct Grocery Initiatives, Transportation Science 39(3): 313-327.

Campbell, A. M.; Savelsbergh, M. 2006. Incentive Schemes for Attended Home Delivery Services, Transportation Science 40(3): 327-341.

Carbone, V.; Roquet, A.; Roussat, C. 2017. The Rise of Crowd Logistics: A New Way to Co-Create Logistics Value, Journal of Business Logistics 38(4): 238-252.

Cárdenas, I.; Beckers, J.; Vanelslander, T. 2017. E-commerce last-mile in Belgium: Developing an external cost delivery index, Research in Transportation Business \& Management 24: 123-129.

Dablanc, L.; Giuliano, G.; Holliday, K.; O’Brien, T. 2013. Best Practices in Urban Freight Management, Transportation Research Record 2379(1): 29-38.

Dablanc, L.; Morganti, E.; Arvidsson, N.; Woxenius, J.; Browne, M.; Saidi, N. 2017. The rise of on-demand "Instant Deliveries" in European cities, Supply Chain Forum: An International Journal 18(4): 203-217.

Daduna, J.R.; Lenz, B. 2005. Online-shopping and changes in mobility, In: Fleischmann, B.; Klose, A. (Eds.), Distribution Logistics: Advanced Solutions to Practical Problems. Springer, 65-84.

De Koster, M. B. M. 2002. Distribution structures for food home shopping, International Journal of Physical Distribution \& Logistics Management 32(5): 362-380.

De Koster, M.B.M. 2003. Distribution strategies for online retailers, IEEE Transactions on Engineering Management 50(4): 448-457.

Devari, A.; Nikolaev, A. G.; He, Q. 2017. Crowdsourcing the last mile delivery of online orders by exploiting the 
social networks of retail store customers, Transportation Research Part E: Logistics and Transportation Review 105: 105-122.

Du, T.C.; Li, E.Y.; Chou, D. 2005. Dynamic vehicle routing for online B2C delivery, Omega 33(1): 33-45.

Ducret, R. 2014. Parcel deliveries and urban logistics: Changes and challenges in the courier express and parcel sector in Europe - The French case, Research in Transportation Business \& Management 11: 15-22.

Durand, B.; Gonzalez-Feliu, J. 2012. Urban Logistics and E-Grocery: Have Proximity Delivery Services a Positive Impact on Shopping Trips? Procedia-Social and Behavioral Sciences 39: 510-520.

Edwards, J. B.; McKinnon, A. C.; Cullinane, S. L. 2010a. Comparative analysis of the carbon footprints of conventional and online retailing, International Journal of Physical Distribution \& Logistics Management 40(1/2): 103-123.

Edwards, J. B.; McKinnon, A. C.; Cullinane, S. L. 2009. Carbon auditing the 'last mile': modelling the impact of conventional and on-line food shopping, Green Logistics Project, Herriott-Watt University, Edinburgh.

Edwards, J.; McKinnon, A.; Cherrett, T.; McLeod, F.; Song, L. 2010b. Carbon dioxide benefits of using collection-delivery points for failed home deliveries in the United Kingdom, Transportation Research Record 2191: 136-143.

Ehmke, J. F.; Mattfeld, D. C. 2012. Vehicle Routing for Attended Home Delivery in City Logistics, Procedia Social and Behavioral Sciences 39: 622-632.

Ehmke,J.F.; Campbell, A.M. 2014. Customer acceptance mechanisms for home deliveries in metropolitan areas, European Journal of Operational Research 233: 193-207.

Esser, K.; Kurte, J. 2005. B2C e-commerce: impact on transport in urban areas. In Recent Advances in City
Logistics, In Proceedings of the 4th International Conference on City Logistics, 437-448.

Fernie, J.; McKinnon, A.C. 2009. The development of e-tail logistics, In Fernie, J.; Sparks, L. (Ed.), Logistics and retail management: emerging issues and new challenges in the retail supply chain, $3^{\text {rd }} \mathrm{Ed}$, Kogan Page, 207-232.

Fernie, J.; Sparks, L.; McKinnon, A. C. 2010. Retail logistics in the UK: past, present and future, International Journal of Retail \& Distribution Management 38(11/12): 894-914.

Gan, X.; Sethi, S. P.; Zhou, J. 2010. Commitmentpenalty contracts in drop-shipping supply chains with asymmetric demand information, European Journal of Operational Research 204(3): 449-462.

Gardrat, M.; Toilier, F.; Patier, D.; Routhier, J. 2016. How can the impact of new practices for supplying households be quantified in urban goods movements, In Proceedings of the $6^{\text {th }}$ International Conference on Information Systems Logistics and Supply Chain, 1-9.

Gevaers, R. 2020. Why COVID might change B2C last mile networks forever, Linkedin blog. Available from internet: https://www.linkedin.com/pulse/whycovid-might-change-b2c-last-mile-networks-forevergevaers-ph-d-/?trackingId=zH3ziDb3Tsia 8 eyxUK\% 2FzkQ\%3D\%3D.

Gevaers, R.; Van de Voorde, E.; Vanelslander, T. 2009. Characteristics of innovations in last-mile logisticsusing best practices, case studies and making the link with green and sustainable logistics. In Proceedings of the European Transport Conference, $21 \mathrm{p}$.

Gevaers, R.; Van de Voorde, E.; Vanelslander, T. 2011. Characteristics and Typology of Last-Mile Logistics from an Innovation Perspective in an Urban Context. In Macharis, C.; Melo, S. (Ed.), City Distribution and Urban Freight Transport: Multiples Perspectives, 56-71. 
Gevaers, R.; Van de Voorde, E.; Vanelslander, T. 2014. Cost Modelling and Simulation of Last-mile Characteristics in an Innovative B2C Supply Chain Environment with Implications on Urban Areas and Cities, Procedia - Social and Behavioral Sciences 125: 398-411.

Gould, J. 1998. Driven to Shop?: Role of Transportation in Future Home Shopping, Transportation Research Record 1617: 149-156.

Hausmann, L.; Herrmann, N.A.; Krause, J.; Netzer, T. 2014. Same-day delivery: The next evolutionary step in parcel logistics (McKinsey \& Company). Available from internet: https://www.mckinsey.com/ /media/ McKinsey/Industries/Travel\%20 Transport $\% 20$ and\%20Logistics/Our\%20Insights/Same\%20day\%20 delivery\%20the $\% 20$ next $\% 20$ evolutionary\%20step $\% 20$ in\%20parcel\%20logistics/Sameday_delivery_The_ next_evolutionary_step_in_parcel_logistics.ashx.

Hays, T.; Keskinocak, P.; De López, V. M. 2005. Strategies and challenges of internet grocery retailing logistics. In Geunes, J. (Ed.), Applications of Supply Chain Management and E-Commerce Research, Springer, 217-252.

Hesse, M. 2002. Shipping news: the implications of electronic commerce for logistics and freight transport, Resources, conservation and recycling 36(3): 211-240.

Hobbs, J. E. 2020. Food supply chains during the COVID-19 pandemic, Canadian Journal of Agricultural Economics 68: 171-176.

Iwan, S.; Kijewska, K.; Lemke, J. 2016. Analysis of Parcel Lockers' Efficiency as the Last Mile Delivery Solution - The Results of the Research in Poland, Transportation Research Procedia 12: 644-655.

Joerss, M.; Schroder, J.; Neuhaus, F.; Klink, C.; Mann, F. 2016. Parcel delivery: the future of last mile, Travel, Transport and Logistics, McKinsey\&Company. 32 p.
Kämäräinen, V.; Punakivi, M. 2002. Developing Costeffective Operations for the e-Grocery Supply Chain, International Journal of Logistics Research and Applications 5(3): 285-298.

Kämäräinen, V.; Saranen, J.; Holmström, J. 2001. The reception box impact on home delivery efficiency in the e-grocery business, International Journal of Physical Distribution \& Logistics Management 31(6): 414-426.

Klein, R.; Neugebauer, M.; Ratkovitch, D.; Steinhardt, C. 2019. Differentiated Time Slot Pricing Under Routing Considerations in Attended Home Delivery, Transportation Science 53(1): 236-255.

Kuhn, H.; Sternbeck, M.G. 2013. Integrative retail logistics: an exploratory study, Operations Management Research 6(1/2): 2-18.

Kull, T. J.; Boyer, K.; Calantone, R. 2007. Last-mile supply chain efficiency: an analysis of learning curves in online ordering, International Journal of Operations \& Production Management 27(4): 409-434.

Lim, S. F. W. T.; Jin, X.; Srai, J. S. 2018. Consumer-driven e-commerce, International Journal of Physical Distribution \& Logistics Management 48(3): 308-332.

Lin, I.; Mahmassani, H. 2002. Can Online Grocers Deliver?: Some Logistics Considerations, Transportation Research Record 1817(1): 17-24.

Lindner, J. 2011. Last mile logistics capability: a multidimensional system requirements analysis for a general modelling and evaluation approach. Dipl. Technical university of Munich.

McKinnon, A. C.; Tallam, D. 2003. Unattended delivery to the home: an assessment of the security implications, International Journal of Retail \& Distribution Management 31(1): 30-41. 
McLeod, F.; Cherrett, T.; Song, L. 2006. Transport impacts of local collection/delivery points, International Journal of Logistics Research and Applications 9(3): 307-317.

Mehmann, J.; Frehe, V.; Teuteberg, F. 2015. Crowd Logistics - A Literature Review and Maturity Model, In Proceedings of the Hamburg International Conference of Logistics (HICL), 117-145.

Menge, J.; Hebes, P. 2011. Optimization of urban deliveries: evaluating a courier, express and parcel services pilot project in Berlin, In Macharis, C.; Melo, S. (Ed.), City Distribution and Urban Freight Transport: Multiples Perspectives. Edward Elgar Publishing, Northampton, 201-216.

Morganosky, M. A.; Cude, B. J. 2000. Consumer response to online grocery shopping, International Journal of Retail \& Distribution Management 28(1): 17-26.

Morganti, E.; Dablanc, L.; Fortin, F. 2014a. Final deliveries for online shopping: The deployment of pickup point networks in urban and suburban areas, Research in Transportation Business \& Management 11: 23-31.

Morganti, E.; Seidel, S.; Blanquart, C.; Dablanc, L.; Lenz, B. 2014b. The impact of e-commerce on final deliveries: alternative parcel delivery services in France and Germany, Transportation Research Procedia 4: 178-190.

Moroz, M.; Polkowski, Z. 2016. The last mile issue and urban logistics: choosing parcel machines in the context of the ecological attitudes of the Y generation consumers purchasing online, Transportation Research Procedia 16: 378-393.

Murphy, A. J. 2003. (Re)solving space and time: Fulfilment issues in online grocery retailing, Environment and Planning A 35(7): 1173-1200.

Oldhager, J. 2003. Strategic positioning of the order penetration point, International Journal of Production Economics 83(3): 319-329.
Ozbaygin, G.; Karasan, O. E.; Savelsbergh, M.; Yaman, H. 2017. A branch-and-price algorithm for the vehicle routing problem with roaming delivery locations, Transportation Research Part B: Methodological 100: 115-137.

Park, H.; Park, D.; Jeong, I.J. 2016. An effects analysis of logistics collaboration in last-mile networks for CEP delivery services, Transport Policy 50: 115-125.

Punakivi, M. 2003. Comparing alternative home delivery models for e-grocery business, $\mathrm{PhD}$ thesis, Helsinki University of Technology, Industrial Engineering and Management, Helsinki. 140 p.

Punakivi, M.; Saranen, J. 2001. Identifying the success factors in e-grocery home delivery, International Journal of Retail \& Distribution Management 29(4): 156-163.

Punakivi, M.; Yrjölä, H.; Holmström, J. 2001. Solving the last mile issue: reception box or delivery box, International Journal of Physical Distribution \& Logistics Management 31(6): 427-439.

Reyes, D.; Savelsbergh, M.; Toriello, A. 2017. Vehicle routing with roaming delivery locations, Transportation Research Part C: Emerging Technologies 80: 71-91.

Siikavirta, H.; Punakivi, M.; Kärkkäinen, M.; Linnanen, L. 2008. Effects of E-Commerce on Greenhouse Gas Emissions: A Case Study of Grocery Home Delivery in Finland, Journal of Industrial Ecology 6(2): 83-97.

Slabinac, M. 2016. Innovative solutions for a "last-mile" delivery-a European experience. In Proceedings of The 15th International Scientific Conference Business Logistics in Modern Management, 111-129.

Song, L.; Cherrett, T.; McLeod, F.; Wei, G. 2009. Addressing the last mile problem. Transport impacts of collection and delivery points, Transportation Research Record 2097(1): 9-18. 
Tadić, S. 2019. City logistics initiatives for central urban zones (In Serbian), Tehnika 69(4): 585-594.

Tadić, S.; Veljović, M. 2020a. Logistics flows of household, Tehnika 75(2): 225-237.

Tadić, S.; Veljović, M. 2020b. Return flows in home delivery. In Proceedings of The $19^{\text {th }}$ International Conference on Transport Science (ICTS), Portoroz, Slovenia, in press.

Tadić, S.; Zečević, S.; Kostadinović, A. 2017. Home delivery - problems and opportunities. In Proceedings of the $6^{\text {th }}$ international conference Towards a Humane City: Smart Mobility - Synergy Between Sustainable Mobility and New Technologies, Faculty of technical sciences, University of Novi Sad, Novi Sad, Serbia, 131-136.

Taniguchi, E.; Kakimoto, Y. 2004. Modelling effects of e-commerce on urban freight transport. In Taniguchi, E.; Thompson, R. G. (Ed.), Logistics systems for suistanable cities, Elsevier, 135-146.

Van Duin, J. H. R.; De Goffau, W.; Wiegmans, B.; Tavasszy, L. A.; Saes, M. 2016. Improving Home Delivery Efficiency by Using Principles of Address Intelligence for B2C Deliveries, Transportation Research Procedia 12: 14-25.

Vanelslander, T.; Deketele, L.; Van Hove, D. 2013. Commonly used e-commerce supply chains for fast moving consumer goods: comparison and suggestions for improvement, International Journal of Logistics Research and Applications 16(3): 243-256.

Visser, J.; Nemoto, T.; Browne, M. 2014. Home Delivery and the Impacts on Urban Freight Transport: A Review, Procedia - Social and Behavioral Sciences 125: 15-27.

Wang, Y.; Zhang, D.; Liu, Q.; Shen, F.; Lee, L. H. 2016. Towards enhancing the last-mile delivery: An effective crowd-tasking model with scalable solutions, Transportation Research Part E: Logistics and Transportation Review 93: 279-293.
Weltevreden, J. W. J. 2008. B2C e-commerce logistics: the rise of collection-and-delivery points in The Netherlands, International Journal of Retail \& Distribution Management 36(8): 638-660.

Weltevreden, J. W.J.; Rotem-Mindali, O. 2009. Mobility effects of $\mathrm{B} 2 \mathrm{C}$ and $\mathrm{C} 2 \mathrm{C}$ e-commerce in the Netherlands: a quantitative assessment, Journal of Transport Geography 17(2): 83-92.

Wohlrab, J.; Harrington, T.S.; Srai, J.S. 2012. Lastmile logistics evaluation - customer, industrial and institutional perspectives, In Proceedings of The $23 \mathrm{rd}$ Annual Production and Operations Management Society (POMS) conference. Chicago, $20 \mathrm{p}$.

Xu, M.; Ferrand, B.; Roberts, M. 2008. The last mile of e-commerce - unattended delivery from the consumers and eTailers' perspectives, International Journal of Electronic Marketing and Retailing 2(1): 20-37.

Yaman, H.; Karasan, O. E.; Kara, B. Y. 2012. Release Time Scheduling and Hub Location for Next-Day Delivery, Operations Research 60(4): 906-917.

Yrjölä, H. 2001. Physical distribution considerations for electronic grocery shopping, International Journal of Physical Distribution \& Logistics Management 31(10): 746-761.

Yuen, K. F.; Wang, X.; Ng, L. T. W.; Wong, Y. D. 2018. An investigation of customers' intention to use selfcollection services for last-mile delivery, Transport Policy 66: 1-8. 